\title{
A120 INTRAVENOUS IMMUNOGLOBULIN PROMOTES APOPTOSIS OF MATURE HUMAN B LYMPHOCYTES BY USING CD22 TO MODULATE THEIR ANTIGEN B CELL RECEPTOR
}

S Hillion, J-F Séité, J-0 Pers, P Youinou EA 2216 'Immunologie et Pathologie' and IFR 148 ScInBioS, Université de Brest, and Université Européenne de Bretagne, Brest, France

10.1136/ard.2010.129635

Background Although widely used to treat inflammatory diseases, the mechanism by which intravenous immunoglobulin (IVIg) modulates immune function is not fully understood.

Materials and Methods B cells from the blood of healthy volunteers and tonsils of children undergoing tonsillectomy, coupled with human Ramos lymphoma line B cells, served to assess the effects of IVIg. This latter was fluoresceinated, or enriched in sialic acid (SA)-bearing fractions using a lectics column.

Results IVIg enhanced spontaneous apoptosis of B cells, by interaction with CD22. This association was established using fluoresceinated IVIg, with SA-deprived human aggregated $\mathrm{F}\left(\mathrm{ab} \mathrm{b}^{\prime}\right) 2$ as a negative control, and was confirmed by subsequent staining and Western blotting experiments. Phosphorylation of CD22 was augmented, whereas that of Lyn and BLNK was reduced, as demonstrated by immunoprecipitation experiments. In contrast, apoptosis was promoted through sustained activation of Erk1 and E2F1 was downregulated.

Conclusion Our data is telling that IVIg binds B lymphocytes by interacting with CD22, thus modulating a number of $B$ cell receptor-mediated signalling pathways. 